useiden yhtäläisyyksien lisäksi myös eroja suomen vastaaviin ilmauksiin. Toivoa sopii myös, että Murmannin tutkimuksessa esille nousseita havaintoja hyödynnettäisiin rektiosijojen S2-opetuksessa. Kielentutkijaa nämä havainnot rohkaisevat jatkopohdintoihin siitä, voisiko suomen tai viron rektioilmiöille olla löydettävissä laajempaakin semanttista motivaatiota.

\section{Tuomas HuUmo thuumo@utu.fi \\ LIINA LINDSTRÖM etunimi.sukunimi@ut.ee}

Tuomas Huumo on Turun yliopiston suomen kielen professori. Liina Lindström on Tarton yliopiston viron kielen dosentti. Hän toimi Murmannin vastaväittäjänä.

\section{Lähteet}

Bossong, Georg 1998: Le marquage de l'expérient dans les langues d'Europe. Jack Feuillet (toim.), Actance et valence dans les langues de l'Europe s. 259-294. Berlin: De Gruyter.

Croft, William 1993: Case marking and the semantics of mental verbs. - James Pustejovsky (toim.), Semantics and the lexicon s. 55-72. Boston: Kluwer Academic Publishers.

Haspelmath, Martin 2001: Noncanonical marking of core arguments in European languages. - Alexandra Y.
Aikhenvald, R. M. W. Dixon \& Masayuki Onishi (toim.), Non-canonical marking of subjects and objects s. 53-84. Amsterdam: Benjamins.

ISK = HAKULINEN, AUli - VILKUNA, Maria - Korhonen, Rittta Koivisto, Vesa - Heinonen Tarja RiIt ta - AlHo, IRJA 2004: Iso suomen kielioppi. Verkkoversio. Helsinki: Suomalaisen Kirjallisuuden Seura. http:// scripta.kotus.fi/visk (10.11.2018).

Murmann, Maximilian (tulossa): Inchoative emotion verbs in Finnish. Argument structures and collexemes. Tübingen: Narr France Attempto Verlag.

NæSS, ÅsHILD 2007: Prototypical transitivity. Amsterdam: John Benjamins.

ONISHI, MASAYUKI. 2001: Non-canonically marked subjects and objects: Parameters and properties. - Alexandra Y. Aikhenvald, R. M. W. Dixon \& Masayuki Onishi (toim.), Non-canonical marking of subjects and objects s. 1-51. Amsterdam: Benjamins.

SiIroinen, Mari 2001: Kuka pelkää ja ketä pelottaa? Nykysuomen tunneverbien kielioppia ja semantiikkaa. Helsinki: Suomalaisen Kirjallisuuden Seura.

Tuovila, Seija 2005: Kun on tunteet. Suomen kielen tunnesanojen semantiikkaa. Oulu: Oulu University Press.

Wierzbicka, Anna 1996: Semantics. Primes and universals. Oxford: Oxford University Press.

\title{
Kun futuuria ei ole
}

Miıa Karttunen: No pittää kahttoo. Puhujan tulevan toiminnan ilmausten kielioppia ja pragmatiikkaa. Publications of the University of Eastern Finland. Dissertations in Education, Humanities, and Theology 119. Joensuu: Itä-Suomen yliopisto 2018. 256 s. ISBN 978-952-61-2711-8.
Miia Karttusen väitöstutkimus koskee puhujan tulevan toiminnan ilmauksia suomen kielessä. Suomessahan varsinaista futuuritempusta ei ole, mutta futuurisia ilmauksia on fennistiikassa jonkin verran kuvattu osana laajempaa tempusjärjestelmän kuvausta (esim. Ikola 1949; Wiik 1976; 
ISK $2004 \$ 1542-1550)$. Futuurisia ilmauksia on tutkittu joissain opinnäytetöissä, mutta yhtään laajaa pelkästään futuurisiin ilmauksiin keskittyvää tutkimusta ei ole aiemmin tehty. Karttusen tutkimusaihe on siis jo aiemman tutkimuksen vähyyden vuoksi kiintoisa. Väitöskirjan tavoitteeksi mainitaan "tuottaa uutta tietoa puhutun suomen kielen futuuristen ilmausten rakenteesta ja käytöstä’ (s. 15). Tämä deskriptiivinen tavoite täyttyy hyvin.

Varsinaisia tutkimuskysymyksiä on kolme: 1) millaisilla lauseilla puhuja viittaa omaan tulevaan toimintaansa, 2) millaisissa pragmaattisissa funktioissa näitä ilmauksia käytetään ja 3) millainen on puhujan tulevan toiminnan ilmausten modaalinen luonne. Tutkimuskysymykset on linkitetty konkreettisesti väitöskirjan lukuihin: Kysymykseen 1 vastataan luvuissa 5-7 kuvaamalla puhujan tulevaan toimintaan viittaavien ilmauksien kieliopillisia ja semanttisia ominaisuuksia valitussa aineistossa. Kysymykseen 2 vastataan luvussa 8 , jossa käsitellään puhujan tulevaan toimintaan viittaavien ilmausten edustamia puhetoimintoja. Modaalisuutta koskevaan kysymykseen 3 saadaan vastauksia kaikissa analyysiluvuissa. Loppuluvussa esitetään kokoavasti vastaukset kuhunkin tutkimuskysymykseen.

Väitöskirja muodostaa harkitun kokonaisuuden ja on esitystavaltaan selkeä. Johdannon jälkeen luvussa 2 käsitellään futuurisuutta ilmiönä, luvussa 3 esitellään aineisto ja luvussa 4 teoreettiset kehykset. Tämän jälkeen seuraavat analyysiluvut 5-8. Väitöskirjan jäsennys yhdeksään päälukuun on onnistunut, ja rakenne tukee hyvin tutkimuskysymysten selvittämistä. Sen sijaan jako alalukuihin on paikoitellen monipolvinen ja vaikeasti seurattava. Analyysiluvuissa aineisto käydään valittujen ominaisuuksien osalta tyhjentävästi läpi. Analyysi on yksityiskohtaista, mutta lukujen lopuissa olevat koonnit auttavat lukijaa poimimaan yksityiskohdista tärkeimmät.

\section{Teoriapohja ja menetelmät}

Tutkimuksen teoreettisina kehyksinä esitellään toisaalta puheaktiteoria, toisaalta vuorovaikutuslingvistiikka ja keskustelunanalyysi. Karttunen sanoo käyttävänsä näitä teoreettisia lähtökohtia "eklektisesti, aineistoanalyysin ehdoilla" (s. 15). Mainitut teoriakehykset näkyvät erityisesti puhetoimintoja käsittelevässä luvussa 8; muut luvut operoivat enimmäkseen perinteisen kieliopin kuvauksen käsittein. Puheaktiteorian ja vuorovaikutuslingvistiikan ja keskustelunanalyysin yhteen sovittamista ja sen hankauskohtia ei kuitenkaan pohdita. Tutkimuksesta ei nouse merkittäviä uusia teoreettisia avauksia.

Tutkimus pohjaa pääosin laadulliseen analyysiin. Aineisto on analysoitu valittujen piirteiden osalta läpikotaisin, ja tulokset raportoidaan yksityiskohtaisesti. Lukija saa tarkan käsityksen siitä, millaisia puhujan tulevaan toimintaan viittaavat ilmaukset aineistossa ovat. Analyysista annetaan myös määrällisiä tietoja, jotka auttavat lukijaa hahmottamaan, mikä on tavanomaista, mikä taas harvinaisempaa. Tilastollisten menetelmien avulla olisi voinut saada aineistosta esiin jotain lisätietoa, mutta samalla ne olisivat voineet tuoda uusia ongelmia, koska aineisto on melko heterogeeninen.

Laadullinen analyysi etenkin luvuissa 5-7 osoittaa hyvää analyysivälineiden hallintaa, ja lukijan on helppo yhtyä esitettyihin analyyseihin. Fennistisen kieliopin tutkimuksen peruskäsitteistön Karttunen hallitsee hyvin. Luvussa 8 hän kuitenkin myöntää, että puhetoimintojen luokittelu on subjektiivista ja rajatapauksia ja päällekkäisyyksiä on paljon (s. 182-183). Voikin kysyä, onko perusteltua ajatella, että puhetoiminnot muodostavat senlaatuisen taksonomian, että niitä on järkevää yrittää luokitella Karttusen valitsemalla yksityiskohtaisuuden tasolla. Tutkimukselle voi kuitenkin antaa kiitosta siitä, että puhetoimintojen analyysi (luku 8) viedään läpi 
yhtä perusteellisesti kuin kieliopillinenkin analyysi (luvut 5-7) tyytymättä vain helppojen tapausten käsittelyyn.

\section{Aineiston rikkaus}

Tutkimuksen aineisto on tunteina mitattuna laaja ja poimittujen ilmausten määrän puolesta riittävä väitöstutkimuksen tarpeisiin. Se on kekseliäästi koottu pääosin olemassa olleista aineslähteistä yhdistellen vanhaa murreaineistoa uuteen aineistoon. Aineslähteet muodostavat erittäin kiinnostavan kokonaisuuden.

Aineisto on rajattu alueellisesti Pohjois-Karjalan ja Kainuun murteisiin. Vaikka se on peräisin murteista, tutkimuksella ei ole varsinaisia dialektologisia tavoitteita. Aineiston valinta liittää tutkimuksen osaksi suuntausta, jossa murreaineistoja tarkastellaan hyödyntäen pragmatiikan ja vuorovaikutuksen tutkimuksen käsitteitä. Tarkasteltavia ilmauksia käsitellään osana laajempaa käyttökontekstiaan. Lähestymistapa ei ole aivan uusi suomalaisella murteentutkimuksen kentällä (vrt. esim. Kok 2016; Väänänen 2016; Priiki 2017; Uusitupa 2017), mutta aiempaan verrattuna uutta Karttusen tutkimuksessa on vuorovaikutuksen analyysi erityisesti puhetoimintojen kannalta: puhujan tulevan toiminnan ilmauksia tarkastellaan meneillään olevan puhetoiminnon valossa.

Aineisto jakautuu keskusteluihin ja haastatteluihin. Yleistysten tekemistä hankaloittaa se, että kummankin aineistoosan sisällä on paljon tilanteista vaihtelua. Keskusteluaineistosta suurin osa on asiointitilanteista, mutta mukana on myös vapaiden keskustelujen tallenteita. Karttunen ottaa tulosten tulkinnassa aineiston sekakoosteisuuden kuitenkin huomioon.

\section{Tutkimuksen anti}

Tutkimuksen tulokset sisältävät kiinnostavia löydöksiä, kuten esimerkiksi sen, että pitää-rakenteet (esim. pittää kahttoo) ovat kaikkein yleisimpiä futuurismerkityksisiä rakenteita tutkitussa aineistossa. Tutkimus osoittaa, että aiemmassa futuurisia ilmauksia koskevassa kirjallisuudessa paljon huomiota saaneet rakenteet ovatkin todellisessa kielenkäytössä harvinaisia tai puuttuvat melkein tyystin.

Puhujan tulevaan toimintaan viittaavien ilmauksien kieliopillisia ja semanttisia ominaisuuksia koskevat analyysit ovat tarkkoja ja asiantuntevia. Puhetoimintoja koskevat analyysit ovat sen sijaan tutkimuksen kiistanalaisinta osaa, ja niissä olisi voinut päätyä myös aivan erilaisiin lopputuloksiin. Pidän kuitenkin hyvänä, että Karttunen on tarttunut puhetoimintoja koskevaan tutkimuskysymykseen ja pyrkinyt siihen vastatessaan samanlaiseen perinpohjaisuuteen kuin kieliopilliseen muotoon ja semantiikkaan liittyvissä analyyseissaan.

Karttusen väitöskirjan suurimpana ansiona pidän puhujan tulevan toiminnan ilmaisemiseen käytettyjen kielellisten keinojen monipuolista kuvausta aidossa puheaineistossa. Työlle asetetut tavoitteet ja tutkimuskysymykset ovat ennen kaikkea deskriptiivisiä; asetetut tavoitteet saavutetaan ja kaikkiin tutkimuskysymyksiin saadaan vastaukset. Teoriakehys on koottu puheaktiteorian ja vuorovaikutuksen tutkimuksen aineksista, ja kehyksen kuvaus on referoiva ennemmin kuin pohtiva.

Miia Karttusen väitöskirja tuottaa merkittävää uutta, aitoon puheaineistoon pohjaavaa tietoa puhujan tulevan toiminnan ilmauksista. Tällaisia ilmauksia ja niiden käyttöä aidoissa diskurssiaineistoissa ei ole juuri kuvattu fennistisissä tutkimuksissa. Yksi syy tähän on se, että aineiston keruu on työlästä, koska suomessa ei ole muodollista futuuritempusta. Morfosyntaktisesti annotoiduistakaan korpuksista ei voi suoraan hakea futuurisia ilmauksia, vaan aineisto on poimittava käsin. Karttunen on käynyt laajan aineiston systemaat- 
tisesti läpi ja koonnut aineistosta kaikki puhujan tulevaan toimintaan viittaavat ilmaukset. Hän piirtää lukijalle monisyisen kuvan näissä ilmauksissa käytetyistä kielellisistä keinoista. Tutkimus avaa uusia näkökulmia murteiden kielioppiin vuorovaikutuksen näkökulmasta.

Marja-LiIsa Helasvuo etunimi.sukunimi@utu.fi

Kirjoittaja on suomen kielen professori Turun yliopistossa. Hän toimi Miia Karttusen vastaväittäjänä.

\section{Lähteet}

Ikola, Osmo 1949: Tempusten ja modusten käyttö ensimmäisessä suomalaisessa Raamatussa verrattuna vanhempaan ja nykyiseen kieleen I. Johdanto. Indikatiivin ja futuuristen liittomuotojen temporaalinen käyttö. Turun yliopiston julkaisuja B: XXXII. Turku: Turun yliopisto.

ISK = HAKULINEN, AUli - Vilkuna, Maria - Korhonen, Rittta Koivisto, Vesa - Heinonen Tarja Rittta - AlHo, IrJA 2004: Iso suomen kielioppi. Helsinki: Suomalaisen Kirjallisuuden Seura.
KoK, Maria 2016: Varjon kieliopillistuminen. Itse-sanan paradigman rakenne ja merkityksenkehitys itäisessä itämerensuomessa. Publications of the University of Eastern Finland. Dissertations in Education, Humanities, and Theology 83. Joensuu: Itä-Suomen yliopisto.

Priski, Katri 2017: Hän, se, tää ja toi? Vuorovaikutussosiolingvistinen tutkimus henkilöviittauksista Kaakkois-Satakunnan nykypuhekielessä. Turun yliopiston julkaisuja, sarja C: 432. Scripta Fennica Edita. Turku: Turun yliopisto.

Uusitupa, Milla 2017: Rajakarjalaismurteiden avoimet persoonaviittaukset. Publications of the University of Eastern Finland. Dissertations in Education, Humanities, and Theology 117. Joensuu: Itä-Suomen yliopisto.

VÄÄnÄnen, Milja 2016: Subjektin ilmaiseminen yksikön ensimmäisessä persoonassa. Tutkimus suomen vanhoista murteista. Turun yliopiston julkaisuja C: 430. Scripta Lingua Fennica Edita. Turku: Turun yliopisto.

Wiik, Kalevi 1976: Suomen tempusten etäja pintarakenteista. - Virittäjä 80 s. $135-162$.

\section{Ensimmäinen kielitieteellinen väitöskirja Kalle Päätalon tuotannosta}

\author{
Sari Keskimaa: Kalle Päätalon lijoki-sarja \\ kielielämäkertana. Acta Universitatis \\ Ouluensis B Humaniora 165. Oulu: Oulun \\ yliopisto 2018. Johdanto 101 s., artikkelit \\ 121 s. ISBN 978-952-62-2053-6.
}

Kaunokirjallisuuden kieli on kiinnostanut suomen kielen tutkijoita jo aivan fennistiikan alusta lähtien. Ensimmäi- set alan tutkijat olivat monitoimimiehiä, joilla oli useita eri rooleja. Varsinaisen tutkimustyön ohella he esimerkiksi kirjoittivat kirja-arvioita, joissa ruodittiin niin suomeksi kirjoitettua kuin käännettyäkin kaunokirjallisuutta. Aikansa nationalistisessa ilmapiirissä huomio kohdistui kielen oikeellisuuteen ja mahdollisiin vierasperäisiin vaikutteisiin. Tiettyä 